\title{
Ginning, spinning, wet processing and fabrication: A means of value addition to organic kapas
}

\author{
SHAILAJA D. NAIK, SADHANA D. KULLOLI AND SHWETA MARIYAPPANAVAR
}

Received: 28.04.2014; Revised: 28.09.2014; Accepted: 11.10 .2014

See end of the paper for authors' affiliations SHWETA MARIYAPPANAVAR Department of Textile and Apparel Designing, College of Rural Home Science, University of Agricultural Science, DHARWAD (KARNATAKA) INDIA Email: shweta.mariyappanavar @gmail.com
ABSTRACT : Organic cotton is grown without pesticides and insecticides and seeds are not genetically modified. India is still the largest producer of organic cotton in the world, accounting for two-third of the global organic cotton production. Textile in the form of fibre, yarn, fabric, garment and fashion accessory is of at most adorable substrate. It is but true that cotton as Kapas (cotton wool with seeds) has very little value as raw goods but the post harvest processes shall definitely fetch better (premium) price. Two varieties of cottons selected for the study were DHH - 11 and DHB - 915. The efficiency of ginning in conversion of Kapas into lint was 49 per cent and remaining 51 per cent was wastage. The efficiency of spinning was 64 per cent and wastage was 36 per cent. Thrash, handling during spinning, wastage during mechanical processing were the main causes for wastage. The quantity of yarn obtained from $10.66 \mathrm{Q}$ of Kapas was $3.36 \mathrm{q}$ almost $1 / 3$ of the total weight; but the returns were 5.82 folds. The calculated profit from Kapas to finished cloth was 29.60 per cent.

KEY WORDS: Organic cotton, Ginning, Spinning, Wet processing, Weaving

- HOW TO CITE THIS PAPER : Naik, Shailaja D., Kulloli, Sadhana D. and Mariyappanavar, Shweta (2014). Ginning, spinning, wet processing and fabrication: A means of value addition to organic kapas. Asian J. Home Sci., 9 (2) : 436-441. 